\title{
The Inhibition by Streptomycin of Certain Streptococcus Bacteriophages, using Host Bacteria Resistant to the Antibiotic
}

\author{
By T. D. BROCK, J. MOSSER AND BARBARA PEACHER \\ Departments of Bacteriology and Microbiology, Indiana \\ University, Bloomington
}

(Received 14 January 1963)

\begin{abstract}
SUMMARY
Streptomycin is a specific antiviral agent for a variety of bacteriophages active against Streptococcus faecium, $S$. faecalis, $S$. liquefaciens and $S$. zymogenes since it inhibits bacteriophage growth even when the host is resistant to the antibiotic. An analysis of the mode of action of the antibiotic in this system reveals that it probably has two effects. If the antibiotic is present before adsorption, it inhibits injection of the phage DNA. This effect is readily reversible. If the antibiotic is added after adsorption, it appears that injection is not inhibited, but that the phage genome is inactivated. The antibiotic has no effect on replication of the phage once the genome has become established in the host cell. This is consistent with the hypothesis that the phage DNA exists transiently at a streptomycin-accessible site, and then moves to a site of replication which is inaccessible to the antibiotic. Streptomycin-resistant phages probably have a different injection mechanism from streptomycin-sensitive phages.

The senior author has reported similar findings for an RNA bacteriophage of Escherichia coli. The implications of this work for virus chemotherapy and for analysing the mode of penetration into the cell of virus nucleic acid are discussed.
\end{abstract}

\section{INTRODUCTION}

In most studies on the effect of antibiotics on bacteriophage growth, the host cells used have been sensitive to the inhibitory agent, so that a specific antiviral effect has not been achieved. We would like to report on a specific antiviral action of streptomycin, under special conditions. This action is revealed by using host bacteria that are completely resistant to the antibiotic.

The initial observation that led to the present work arose when attempts were made to assay certain streptococcus bacteriophages on streptomycin agar, using a resistant host. No plaques were obtained. The specificity of the effect was shown by the fact that certain other bacteriophages attacking the same host were almost completely unaffected. Because of the detailed knowledge of the chemistry and biology of the bacteriophages of Escherichia coli, tests were made of the effect of streptomycin on replication of this group. All of the DNA viruses tested were resistant, but an RNA virus was sensitive (Brock, 1962). The data from a detailed analysis with this system were consistent with the hypothesis that the genome of the RNA phage existed transiently after adsorption at a site accessible to streptomycin, and then moved to a streptomycin-inaccessible site. 
The similarity of the present findings to those with the Escherichia coli RNA virus will be stressed, although the streptomycin-sensitive Streptococcus faecium viruses appear to contain DNA instead of RNA.

\section{MATERIALS}

\section{Bacteria}

In most of the work the host bacterium was Streptococcus faecalis $\mathrm{R}$ (ATCC 8043), although this strain better fits the characteristics used to delineate $S$.faecium (Barnes, 1956). The isolate used in the present work was obtained from the Indiana University culture collection and differs in bacteriophage sensitivity from another isolate of the same culture obtained from the Sloan-Kettering Institute, labelled by them SF/O. Specifically, the I.U. isolate is sensitive to the whole range of bacteriophages discussed here, while the S.K.I. isolate is resistant to $\mathbf{P 3}$ and sensitive to the other viruses. The I.U. culture (designated here as X13) has been used exclusively in this work. This organism is inhibited by $250 \mu \mathrm{g}$. streptomycin $/ \mathrm{ml}$. but not by $125 \mu \mathrm{g} . / \mathrm{ml}$. A mutant of $\times 13$, designated $\times 13 \mathrm{~s}$, resistant to $1000 \mu \mathrm{g}$. antibiotic/ml., was isolated by plating a large population of cells on streptomycinagar plates and picking a colony. Other bacteria used are listed in Table 1. Streptomycin-resistant mutants for all these strains were isolated.

Table 1. Bacteria and bacteriophages

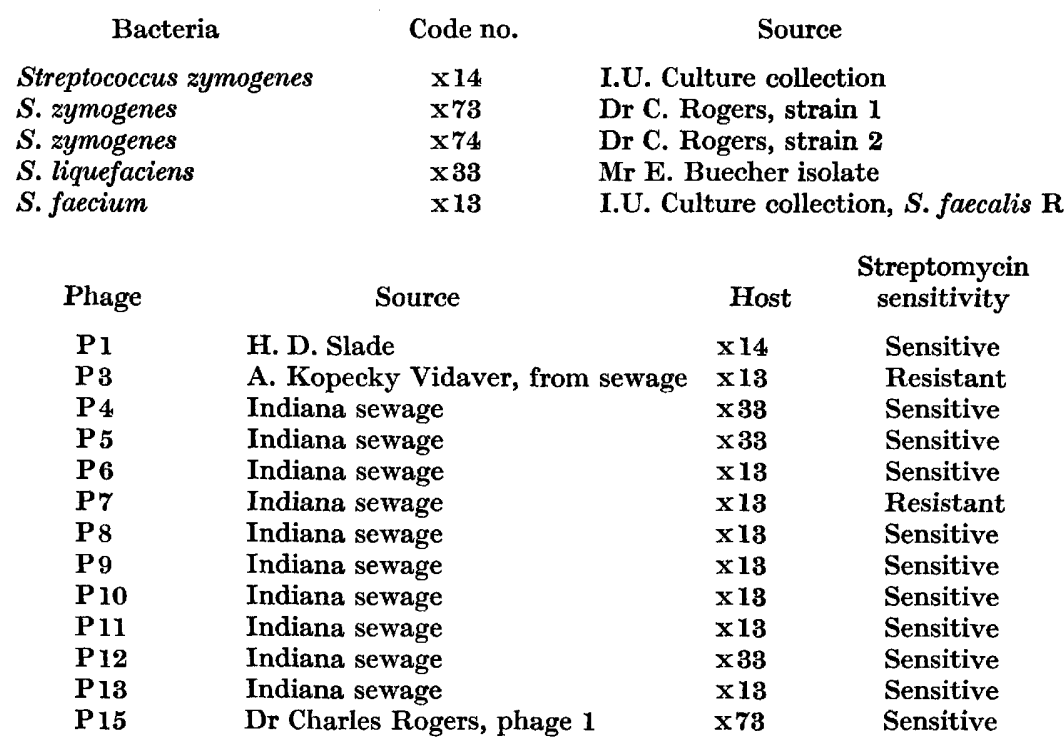

\section{Bacteriophage}

The sources of the bacteriophages are listed in Table $1 . P 3, P 6, P 7, P 8, P 9$, $P 10, P 11$ and $P 13$ all attack strain $\times 13$. Bacteriophages $P 3$ and $P 7$ are similar in plaque size and plaque morphology, are resistant to streptomycin, and differ distinctly from the others. All of the other phages active against $x 13$ are sensitive to streptomycin and'are serologically related. Each bacteriophage can be distinguished 
from all the others by its differential action on a series of phage-resistant mutants. All of the detailed work reported below has been done with P9.

\section{Media and bacteriophage titrations}

Todd-Hewitt broth and agar (Difco Laboratories, Detroit, Michigan) have been used exclusively. For bacteriophage titrations, bottom agar was $30 \mathrm{ml}$. of ToddHewitt broth with $1.5 \%$ agar; top agar was $2 \mathrm{ml}$. of Todd-Hewitt broth with $0.75 \%$ agar. All bacteriophage dilutions were made in Todd-Hewitt broth and $0.1 \mathrm{ml}$. of the final dilution added to the soft agar tube before pouring. The phage-sensitive culture (strain $\times 13 \mathrm{~s}$ ) was grown to an o.D. of 0.500 (Bausch and Lomb Colorimeter, $640 \mathrm{~m} \mu, 16 \mathrm{~mm}$. tube), and kept cold until needed. $0 \cdot 1 \mathrm{ml}$. was added to each soft agar tube before pouring. At an o.D. of 0.500, strain $\times 13 \mathrm{~s}$ had around $3.5 \times 10^{8} \mathrm{chains} / \mathrm{ml}$. and $6 \times 10^{8} \mathrm{cocci} / \mathrm{ml}$. When streptomycin was to be used, it was usually added at a concentration of $1000 \mu \mathrm{g}$. streptomycin sulphate/ml. (Nutritional Biochemicals Co.); the appropriate amount of powder was added in dry form directly to the broth or melted agar. No attempt was made to sterilize the antibiotic and at this concentration contamination did not occur. All incubations were at $37^{\circ}$.

\section{One-step growth curves}

Strains $\times 13 \mathrm{~s}$ was grown to an $0 . \mathrm{D}$. of $0.500\left(6 \times 10^{8}\right.$ cocci $/ \mathrm{ml}$.) and kept cool until needed. The appropriate amount of suspension was mixed with the appropriate amount of $\mathrm{P} 9$ lysate in a $10 \mathrm{ml}$. total volume and incubated at $37^{\circ}$. After adsorption the suspension was filtered on a membrane filter (Millipore Type HA), washed with $20 \mathrm{ml}$. broth, and then suspended in $10 \mathrm{ml}$. broth. The suspension from the filter was then diluted and this dilution incubated for the growth experiments. Samples of $0.05 \mathrm{ml}$. were removed and diluted in Todd-Hewitt broth for phage assays. Duplicate samples of $0.1 \mathrm{ml}$. were treated with $0.05 \mathrm{ml}$. chloroform for $10 \mathrm{~min}$. at $37^{\circ}$ and then diluted and assayed, to give an estimate of intracellular mature phage.

\section{Analyses}

RNA and DNA analyses of phage P9 were performed on hot perchloric acid extracts of purified phage suspensions using the methods of Chargaff \& Davidson (1955) and Burton (1956) respectively, using yeast RNA and thymus DNA as standards.

\section{Antiserum}

Antiserum against P9 was prepared by repeatedly injecting rabbits subcutaneously or in the foot pad with $0.5-2 \mathrm{ml}$. volumes of a mixture of equal parts Freund's adjuvant (Colorado Serum Co.) and P9 suspension that assayed $2 \times 10^{11}$ / $\mathrm{ml}$. The ' $K$ ' value of Adams (1959) was used to estimate the neutralizing power of the antiserums.

\section{Binding of radioactive streptomycin}

Mono-tritiostreptomycin was a gift of Dr C. Hurwitz. It was used at a specific activity of $1.44 \mathrm{mc} . / \mathrm{mg}$. and an antibiotic concentration of $1 \mathrm{mg} . / \mathrm{ml}$. in ToddHewitt broth. Binding was measured by incubating $\times 13$ or $\times 13 \mathrm{~s}$ cocci at $2 \times 10^{8}$ cocci $/ \mathrm{ml}$. with the radioactive antibiotic for various periods of time and then filtering 0.5 ml. samples on membrane filters (Millipore Type HA), washing with $2 \mathrm{ml}$. 
broth, drying, and counting in a Nuclear-Chicago Co. windowless gas flow counter. Control experiments had shown that there was no self-adsorption under these conditions.

\section{Electron microscopy}

Partially purified suspensions of P9 were sprayed or dropped on collodion films, shadowed with palladium at a 3:1 angle, and examined in an RCA EMU-3C electron microscope. The phage suspensions were sometimes mixed with equal amounts of $2 \%$ potassium phosphotungstate containing $2 \%$ sucrose and sprayed on carbon grids. Other phages were observed without purification by the method of Dawson, Smillie \& Norris (1962).

\section{RESULTS}

\section{Preliminary observations on streptomycin-sensitivity of the bacteriophages}

When lysates of the various bacteriophages which attack strain $\times 13 \mathrm{~s}$ were assayed on plain and streptomycin agar, the results in Table 2 were obtained. It can be seen that $\mathrm{P} 3$ and $\mathrm{P} 7$ were almost completely resistant, whereas P6, P 8, P9, P10, P11 and P 13 formed no plaques on streptomycin plates even when $0 \cdot 1 \mathrm{ml}$. of undiluted lysate was plated. These results show that the action of streptomycin depends on the phage strain and not on the host bacteria, indicating that streptomycin is having a specific antiviral effect.

Table 2. Effect of streptomycin on plaque formation of several Streptococcus faecium bacteriophages

\begin{tabular}{|c|c|c|c|}
\hline \multirow{3}{*}{$\begin{array}{l}\text { Phage } \\
\text { strain }\end{array}$} & \multicolumn{2}{|c|}{ Plain agar } & \multirow{3}{*}{$\begin{array}{c}\text { Streptomycin } \\
\text { agar } \\
\times 13 \mathrm{~s} \text { indicator }\end{array}$} \\
\hline & & $\times 13 \mathrm{~s}$ indicator & \\
\hline & \multicolumn{2}{|c|}{ Plaque count $/ \mathrm{ml}$. crude lysate } & \\
\hline P3 & $1.8 \times 10^{10}$ & $2.3 \times 10^{10}$ & $7 \cdot 8 \times 10^{9}$ \\
\hline P 6 & $4.7 \times 10^{6}$ & $2.8 \times 10^{6}$ & $<10^{1}$ \\
\hline $\mathbf{P r}$ & $8.6 \times 10^{9}$ & $1.2 \times 10^{10}$ & $5.5 \times 10^{9}$ \\
\hline P 8 & $2.8 \times 10^{8}$ & $2.0 \times 10^{8}$ & $<10^{1}$ \\
\hline P9 & $3 \cdot 7 \times 10^{9}$ & $4.2 \times 10^{9}$ & $<10^{1}$ \\
\hline P 10 & $2 \cdot 0 \times 10^{9}$ & $1.8 \times 10^{8}$ & $<10^{1}$ \\
\hline P 11 & $3.5 \times 10^{7}$ & $1.0 \times 10^{7}$ & $<10^{1}$ \\
\hline P 13 & - & $1.5 \times 10^{7}$ & $<10^{1}$ \\
\hline
\end{tabular}

Phages assayed by the soft-agar method on agar with or without $1000 \mu \mathrm{g}$. streptomycin sulphate/ml.

Tests with bacteriophages which attack other hosts indicated that phages $\mathbf{P 1}$, P4, P 5, P12 and P15 were also sensitive to streptomycin. However, several temperate phages which attack $\times 33$ are resistant to the antibiotic. These results further emphasize that streptomycin-sensitivity depends on the phage rather than the host cell. 


\section{Characteristics of the streptomycin-sensitive bacteriophages of strain $\times 13$}

Each of the streptomycin-sensitive phages which attack $\mathrm{x} 13$ was an independent isolate from a different sewage sample. By isolating a series of phage-resistant $\mathrm{x} 13$ mutants, it could be shown that each of the phages could be distinguished by its differential action on this series of mutants. The streptomycin-sensitive phages were all similar in plaque size, plaque morphology, and rate of growth, whereas the streptomycin-resistant phages, $\mathbf{P} 3$ and $\mathbf{P} 7$, differed markedly from the others in these characteristics. All six streptomycin-sensitive phages were neutralized by $\mathbf{P 9}$ antiserum, whereas the streptomycin-resistant phages were not neutralized. The streptomycin-sensitive phages which attack strains other than $\mathrm{x} 13$ were not neutralized by P9 antiserum. Thus streptomycin-sensitivity is not confined to one serological group of phages, although all of the streptomycin-sensitive phages of $x 13$ were serologically related.

\section{Characteristics of the streptomycin-resistant host}

In all the work to follow, $\mathrm{x} 13 \mathrm{~s}$ was used with phage P9. The complete resistance to streptomycin of the $x 13 \mathrm{~s}$ host should be emphasized, since it is crucial to the hypothesis that the antibiotic is having a specific antiviral effect. The mutant formed equal numbers of colonies of equal size on both plain agar plates and on agar plates containing $1000 \mu \mathrm{g}$. streptomycin $/ \mathrm{ml}$. When $1000 \mu \mathrm{g}$. antibiotic $/ \mathrm{ml}$. was added to an exponentially growing culture, the growth rate was unchanged. The sensitive strain bound $2 \times 10^{4}$ molecules/coccus after $2 \mathrm{hr}$. incubation in $1000 \mu \mathrm{g}$. antibiotic/ml., while the resistant mutant bound about 400 molecules/coccus (this is at the limit of sensitivity of the method). The growth rate in streptomycin-broth of $x 13 \mathrm{~s}$ was the same as that of $x 13$. The resistant mutant remained sensitive to the whole range of bacteriophages attacking $\times 13$ and the efficiency of plating on both strains was about the same. Strain $\times 13 \mathrm{~s}$ has remained unchanged in its resistance after cultivation in the absence of the antibiotic for two years.

\section{Characterization of phage $\mathbf{P 9}$}

Because it had been shown in Escherichia coli that only an RNA bacteriophage was streptomycin-sensitive (Brock, 1962), it was of interest to determine the nucleic acid content and morphology of $\mathbf{P 9}$.

Four litres of P9 lysate of a titre of $2.5 \times 10^{10} / \mathrm{ml}$. were prepared. After cooling, dry ammonium sulphate was added to $90 \%$ saturation, and the precipitate that formed was allowed to settle overnight. The almost clear supernatant was siphoned off and the solids in about $500 \mathrm{ml}$. volume were centrifuged at $12,000 \mathrm{~g}$ for $1 \mathrm{hr}$. The brownish black pellet was suspended in $100 \mathrm{ml}$. distilled water to give a suspension with a titre of $1.5 \times 10^{11} / \mathrm{ml}$. containing $35 \%$ of the original phage. This suspension was centrifuged at $12,000 \mathrm{~g}$ for $15 \mathrm{~min}$. and the supernatant obtained was then centrifuged at $39,000 \mathrm{~g}$ for $30 \mathrm{~min}$. The pellet obtained was suspended in $10 \mathrm{ml}$. distilled water to give a suspension with a titre of $1 \cdot 6 \times 10^{11} / \mathrm{ml}$. This suspension was adjusted to $\mathrm{pH} 8$ with $1 \mathrm{~N}-\mathrm{NaOH}$, and $100 \mu \mathrm{g} . / \mathrm{ml}$. each of RNAse and DNAse were added, followed by incubation for $2 \mathrm{hr}$. at $37^{\circ}$. The suspension was then centrifuged at $39,000 \mathrm{~g}$ for $1 \mathrm{hr}$. and the black pellet was suspended in $1 \mathrm{ml}$. distilled water giving a titre of $3 \cdot 34 \times 10^{11} / \mathrm{ml}$. Although in this purification more phage 
could have been recovered by centrifuging at higher speed, the aim was to obtain as clean a fraction as possible.

From this final fraction, $0.5 \mathrm{ml}$. was added to $2 \mathrm{ml} .0 .5 \mathrm{~N}$-perchloric acid and heated at $100^{\circ}$ for $20 \mathrm{~min}$., cooled, centrifuged, and the supernatant used for RNA and DNA assays. No RNA was detectable, but there was $350 \mu \mathrm{g}$. DNA/ml. phage suspension. Thus this preparation contains $1.06 \times 10^{-9} \mu \mathrm{g}$. DNA/plaque-forming unit. No claim is made that the preparation analysed is pure, but it seems safe to conclude that the nucleic acid of phage P9 is DNA rather than RNA.

The morphology of $\mathbf{P} \mathbf{9}$ from the purified preparation was determined by electron microscopy. Most of the particles in shadowed preparations had a head diameter of $50-55 \mathrm{~m} \mu$, a tail diameter of $10-12 \mathrm{~m} \mu$, and a tail length of $220 \mathrm{~m} \mu$. A small, distinct knob could be seen at the tip of the tail, but there was no evidence of tail fibres. In preparations negatively stained with phosphotungstate it was possible to see a thin hole up the centre of the tail which led into the head. Occasional collapsed heads appeared filled with phosphotungstate, and the protein coat of the head could be clearly seen. These particles are quite typical of many DNA phages and bear no resemblance to the streptomycin-sensitive RNA phage of $\boldsymbol{E}$. coli (Loeb \& Zinder, 1961). Electron micrographs of phages P1, P4, P10, P13 and P15 revealed that they all had a typical appearance, with large heads and long narrow tails with complete absence of tail fibres.

\section{Minimum inhibitory concentration of streptomycin}

The minimum concentration of streptomycin necessary to inhibit $\mathbf{P} 9$ replication on plates was about $100 \mu \mathrm{g} . / \mathrm{ml}$. This was approximately the same concentration that was effective with the RNA phage of Escherichia coli (Brock, 1962). Since the parent streptomycin-sensitive strain, $x 13$, grows at this concentration of streptomycin, it was possible to show that streptomycin would also inhibit P9 replication in this strain. Thus the streptomycin effect is not restricted to the antibioticresistant host, but the use of the antibiotic-resistant host makes it possible to use higher concentrations of streptomycin.

Table 3. Effect of streptomycin on free $\mathrm{P9}$ phage particles

$\begin{array}{cccccc}\begin{array}{c}\text { Time } \\ \text { (hr.) }\end{array} & \text { Expt. 1 } & \begin{array}{c}\text { Inacti- } \\ \text { vation } \\ (\%)\end{array} & \begin{array}{c}\text { Time } \\ (\text { min. })\end{array} & \text { Expt. 2 } & \begin{array}{c}\text { Inactivation } \\ (\%)\end{array} \\ 0 & 2 \cdot 42 \times 10^{9} / \mathrm{ml} . & - & 0 & 1 \cdot 1 \times 10^{6} / \mathrm{ml} . & - \\ 1 & 1.26 \times 10^{9} / \mathrm{ml} . & 48 & 5 & 8.2 \times 10^{5} / \mathrm{ml} . & 35 \\ 2 & 1.49 \times 10^{9} / \mathrm{ml} . & 38 & 15 & 6 \cdot 5 \times 10^{5} / \mathrm{ml} . & 41 \\ 3 & 1.65 \times 10^{9} / \mathrm{ml} . & 32 & 60 & 2 \cdot 8 \times 10^{5} / \mathrm{ml} . & 75 \\ 4 & 8.5 \times 10^{8} / \mathrm{ml} . & 65 & 120 & 9 \cdot 0 \times 10^{4} / \mathrm{ml} . & 92\end{array}$

$1000 \mu \mathrm{g}$. streptomycin sulphate/ml. added to a P9 lysate and the titre determined at various times after incubation at $37^{\circ}$.

\section{Action of streptomycin on free phage}

It has been known for many years that high concentrations of streptomycin $(5000 \mu \mathrm{g} . / \mathrm{ml}$.) will slowly inactivate free T2 particles (Cohen, 1947). To measure the effect of the antibiotic on P9, $1000 \mu \mathrm{g} . / \mathrm{ml}$. was added to a P9 lysate and the titre measured at various times after incubation at $37^{\circ}$ (Table 3 ). 
There is only a slow drop in titre over this period and this decrease cannot account for the fact that the antibiotic prevented the appearance of plaques when as many as $10^{10}$ plaque-forming units $/ \mathrm{ml}$. were plated on streptomycin agar.

\section{Action of streptomycin on adsorption of phage P9}

Phage P9 was found to adsorb very slowly and this fact complicated the experiments on the effect of streptomycin on adsorption. By reducing the multiplicity of phage: bacterium to a very low level, and by using an adsorption time of $15 \mathrm{~min}$., it was possible to achieve 50-90\% adsorption (Table 4 ).

Table 4. Effect of streptomycin on adsorption of phage $\boldsymbol{P 9}$

\begin{tabular}{|c|c|c|c|}
\hline & $\begin{array}{c}\text { Titre } \\
\text { (plaque-forming } \\
\text { units } / \mathrm{ml} .)\end{array}$ & $\begin{array}{c}\text { Adsorption } \\
(\%)\end{array}$ & $\begin{array}{c}\text { Inhibition } \\
(\%)\end{array}$ \\
\hline \multicolumn{4}{|l|}{ Expt. 1} \\
\hline No cells, no SM & $7 \cdot 9 \times 10^{5}$ & - & - \\
\hline No cells, SM present & $5 \cdot 2 \times 10^{5}$ & - & - \\
\hline Cells $\left(5 \times 10^{8} / \mathrm{ml}\right)$, no $\mathrm{SM}$ & $8 \times 10^{4}$ & 90 & - \\
\hline Cells $\left(5 \times 10^{8} / \mathrm{ml}.\right)$, SM present & $3 \times 10^{5}$ & 42 & 53 \\
\hline \multicolumn{4}{|l|}{ Expt. 2} \\
\hline No cells, no SM & $7 \times 10^{5}$ & - & - \\
\hline No cells, SM present & $7 \times 10^{5}$ & - & - \\
\hline Cells $\left(5 \times 10^{9} / \mathrm{ml}.\right)$, no SM & $3.3 \times 10^{4}$ & 53 & - \\
\hline Cells $5 \times 10^{9} / \mathrm{ml}$.), SM present & $2 \cdot 3 \times 10^{4}$ & 66 & $\mathbf{0}$ \\
\hline Cells $\left(5 \times 10^{8} / \mathrm{ml}.\right)$, no SM & $8.4 \times 10^{4}$ & 71 & - \\
\hline Cells $\left(5 \times 10^{8} / \mathrm{ml}.\right)$, SM present & $2.7 \times 10^{5}$ & 49 & 31 \\
\hline
\end{tabular}

Adsorption time, $15 \mathrm{~min}$., $37^{\circ} .1000 \mu \mathrm{g}$. streptomycin sulphate $/ \mathrm{ml}$. After incubation, cells were removed by centrifugation at 10,000 r.p.m. for 3 min. and the supernatant assayed for phage. Percentage adsorption in the streptomycin series is calculated using as a base-line the tube lacking cells but containing streptomycin.

The greatest inhibition of adsorption by streptomycin is about $50 \%$. These experiments are complicated by the fact that streptomycin is also able to inactivate free phage (see previous section) and it is not clear whether the adsorption in the streptomycin series should be calculated using a control lacking cells but containing streptomycin, or a control lacking both cells and streptomycin. When a high cell concentration $\left(5 \times 10^{9} / \mathrm{ml}\right.$.) is used, streptomycin did not inhibit adsorption. It is possible that streptomycin does not inhibit adsorption by combining with the cells and blocking the receptor sites, but by combining with the virus particle and blocking a specific site on the phage tail. Since the greatest inhibition of adsorption was about $50 \%$, it seems unlikely that this effect can account for the total antiviral action of the antibiotic.

\section{Influence of streptomycin on replication of phage $P 9$}

The influence of streptomycin on replication has been studied in a series of experiments in which one-step growth curves were performed with addition of streptomycin at various times before or after infection. Because of the slow rate of adsorption of $\mathbf{P 9}$, high multiplicities were used to achieve significant numbers of infected cells at short adsorption times. 
Streptomycin was added before adsorption and then diluted out to allow growth of the control (Fig. 1). On the assumption that the initial phage titre in the chloroform-treated samples represents free phage (in control experiments it could be shown that free phage did occur in the growth tube as a result of unadsorbed phage particles that were trapped in the filter), it is seen that about $99 \%$ of the assayable plaqueforming units were infected centres. In the control the latent period was about 30 min., and the initial burst was about 100. Since adsorption and filtration took about 6-10 min., the actual latent period was between 30 and $40 \mathrm{~min}$. The results do not conform exactly to a one-step growth curve, since the titre continued to rise at a reduced rate after the initial burst, but it is likely that this secondary rise was due to readsorption of released phage on to uninfected cells, probably in the same chain of cocci. Under conditions achieved later (Fig. 2) this secondary rise did not

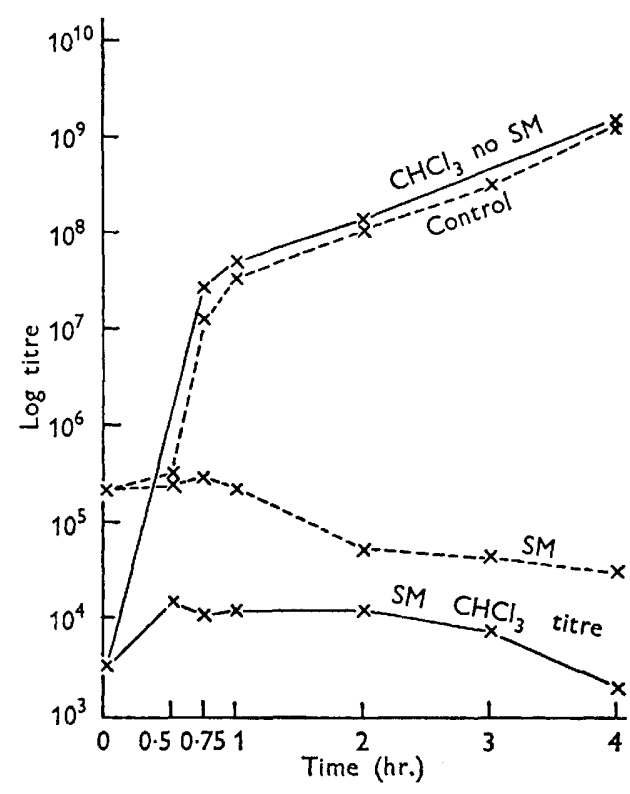

Fig. 1

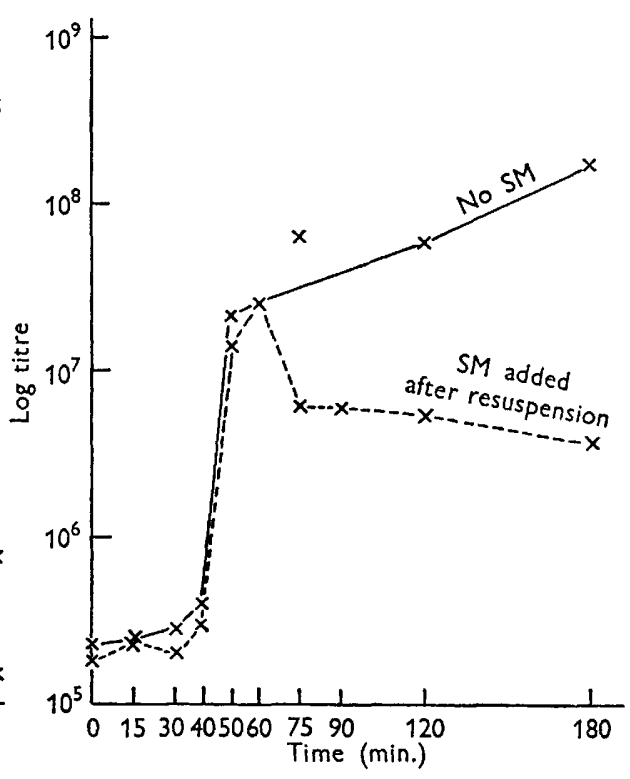

Fig. 2

Fig. 1. Effect of streptomycin (SM) on $P 9$ replication. Cells at $6 \times 10^{7} / \mathrm{ml}$. infected in the presence of $1000 \mu \mathrm{g}$. streptomycin $/ \mathrm{ml}$. with $3 \times 10^{9}$ plaque-forming units $/ \mathrm{ml}$., adsorption $5 \mathrm{~min}$. at $37^{\circ}$, then mixture filtered, washed, and resuspended in streptomycin-containing broth. After resuspension, one sample diluted 1/100 in plain medium and one sample diluted $1 / 100$ in streptomycin-containing broth. Zero time is the point when this last dilution was made. Parallel titrations of untreated and chloroform-treated samples.

Fig. 2. Effect of time of addition of streptomycin on $\mathbf{P 9}$ replication after adsorption in antibiotic-free medium for $5 \mathrm{~min}$. Cells $\left(6 \times 10^{7} / \mathrm{ml}\right.$.) were infected with P9 $\left(1 \times 10^{9} / \mathrm{ml}\right.$. $)$ in the absence of streptomycin, incubated for $5 \mathrm{~min}$. at $37^{\circ}$, filtered to remove free phage, diluted $1 / 100$ and resuspended in plain broth. $1000 \mu \mathrm{g}$. streptomycin sulphate/ml. was added to one tube immediately after dilution, and phage titres made after incubation at $37^{\circ}$.

occur. The present results (Fig. 1) show that a productive infection could occur when adsorption had taken place in the presence of streptomycin. The latent period was similar to that obtained when the whole growth cycle occurred in the absence 
of the antibiotic. As Fig. 1 also shows, streptomycin was able to inhibit replication completely, and the number of infected centres gradually decreased over a 4-hr. period. The fact that the titre of the chloroform samples was at least tenfold lower throughout this period indicates that most of the infected cells retained their phage complement in a form which differed from that of mature phage particles. Since most of these infected cells gave rise to plaques when they were diluted out of the antibiotic, it follows that under the stated conditions many of the phage genomes remained intact throughout the 4-hr. incubation period. The reversibility of the inhibition will be discussed in more detail below. The experiment (Fig. 1) has been repeated a number of times with minor modifications and essentially the same results have been obtained each time. Another experiment indicates that streptomycin inhibition was reversible even after $6 \mathrm{hr}$. incubation under conditions in which the culture was diluted continuously to keep it in the exponential phase of growth.

\section{Reversibility of streptomycin inhibition}

Cells were infected in the presence of $1000 \mu \mathrm{g}$. streptomycin $/ \mathrm{ml}$. and incubated for 30 min., the normal latent period in the absence of the antibiotic. The suspension was then filtered to remove the antibiotic, suspended in fresh medium, and assayed periodically to determine the latent period. No replication occurred in the presence of the antibiotic and a normal latent period occurred upon removal of the antibiotic. Titrations during the period of streptomycin treatment showed that inhibition of replication was complete and that there was no drop in phage titre. Titres of the chloroform samples showed that replication began almost as soon as the antibiotic was removed.

\section{Effect of time of addition of streptomycin in relation to time of infection}

It has been shown above (Fig. 1) that streptomycin can inhibit replication completely when added before infection. A series of experiments were performed to see whether streptomycin would inhibit when added after infection. In the initial series, a 5-min. adsorption time was used, the free phage was removed by filtration, and the antibiotic was added to the infected cells at various times after resuspension. The results in Fig. 2 are in striking contrast to those in Fig. 1. No inhibition was obtained even when the antibiotic was added immediately after resuspension (about 6 min. after initial infection), and similar results were obtained when the antibiotic was added later during the latent period. The latent period and initial burst were identical to that in the control. However, one difference was noted in the period after the initial burst. The control suspension showed a secondary increase in titre (also noted in Fig. 1), while the streptomycintreated suspension did not show this secondary rise, but showed a slight decrease in titre. Apparently the secondary rise in titre is due to the adsorption of released phage on to unlysed cells and subsequent replication, and this latter replication is inhibited by the antibiotic.

To examine this point further, adsorption time was decreased from 5 to $1 \mathrm{~min}$. and the antibiotic added after removal of free phage (Fig. 3). Under these conditions a quite different result was obtained. The phage titre in the streptomycin-treated sample did not remain constant, as in the earlier experiment (Fig. 1), but decreased 
rapidly to about one-tenth the initial value and was not increased by the removal of the streptomycin at any later time. The difference between this experiment and that described in Fig. 1 was that in the latter streptomycin was present before infection, whereas in the former the antibiotic was added shortly after adsorption.

To study this further cells were infected, filtered, washed and resuspended, all in the presence of streptomycin, and then diluted 1/100 to remove the antibiotic. At various times streptomycin was added again and samples plated for infected centres. Under these conditions (Fig. 4) the antibiotic brings about the destruction of infected centres when added at 1, 2, 3 and 4 min. after dilution, but not when added at 6 or $10 \mathrm{~min}$. If the antibiotic is present throughout, there is no loss of infected centres.

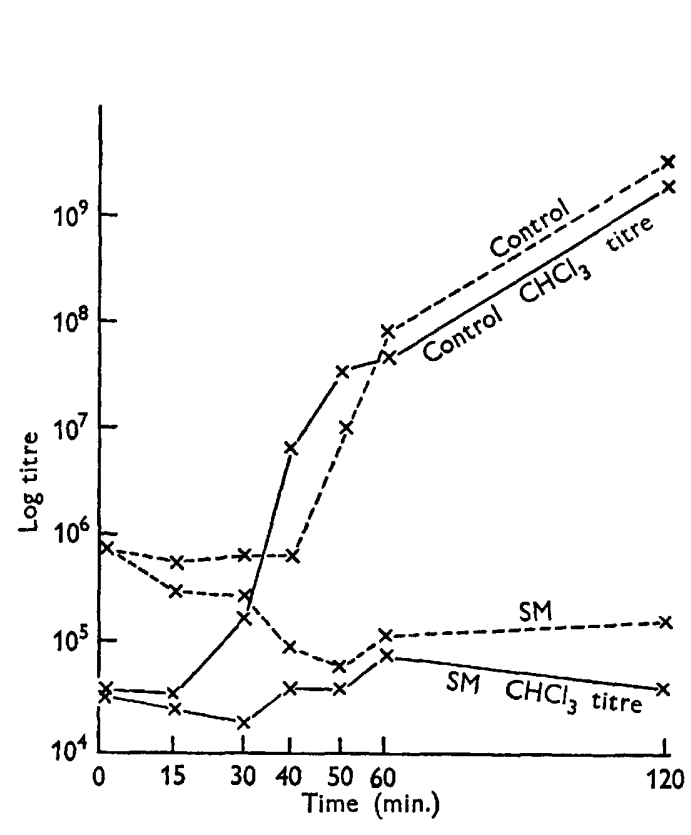

Fig. 3

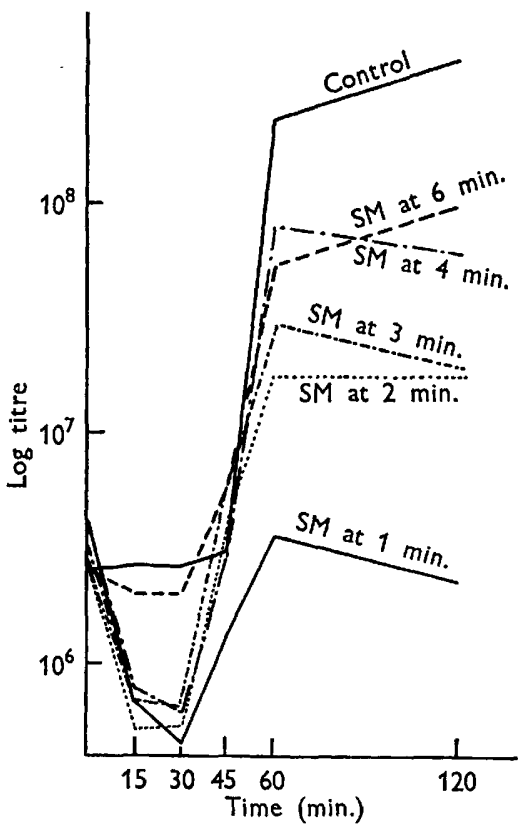

Fig. 4

Fig. 3. Addition of streptomycin after 1 min. adsorption period. Cells $\left(4 \cdot 8 \times 10^{8}\right.$ cocci/ ml.) were infected with P9 $\left(6 \times 10^{9} / \mathrm{ml}\right.$.) for $1 \mathrm{~min}$. in the absence of streptomycin, quickly filtered, washed on the filter and suspended in streptomycin-containing broth at the same cell concentration, and diluted 1/100 in streptomycin-containing broth. A parallel series was run in the complete absence of the antibiotic. Both samples were assayed at various times with chloroform-treated and untreated samples.

Fig. 4. Inactivation of infected centres at different times after infection. Cells $\left(4 \cdot 8 \times 10^{8}\right.$ cocci $/ \mathrm{ml}$.) were infected with $P 9\left(6 \times 10^{9} / \mathrm{ml}\right.$.) in the presence of $1000 \mu \mathrm{g}$. streptomycin sulphate/ml., incubated for $5 \mathrm{~min}$. for adsorption, filtered, washed, and resuspended in the presence of the antibiotic. Infected cells were then diluted 1/100 in streptomycinfree medium, incubated, and at stated intervals the antibiotic was added back.

Streptomycin thus apparently has two effects on P9. If added before adsorption, it inhibits injection of the DNA, and the phage-cell complex remains arrested. If adsorption occurs in the absence of the antibiotic, injection of the phage DNA begins, but the DNA remains for 4-5 min. at a site accessible to the antibiotic. The 
antibiotic can then combine with the DNA and directly or indirectly bring about its destruction. After the phage DNA has passed to an antibiotic-inaccessible site, the antibiotic has no effect and normal replication occurs.

\section{Nature of the inactivation process}

Experiments were performed to analyse the inactivation process brought about by the antibiotic when added during the first 4-5 min. after adsorption. Loss in infected centres begins without a lag upon addition of the antibiotic, and continues at a logarithmic rate for about $\mathbf{3 0} \mathrm{min}$., at which time the titre is about ten times less than the initial value. The rate of inactivation depends upon the temperature since it does not occur if the cells are cooled to $0^{\circ}$ immediately after the streptomycin is added. Addition of the enzymes deoxyribonuclease or chymotrypsin at concentrations of $200 \mu \mathrm{g} . / \mathrm{ml}$. does not increase the rate of streptomycin-induced inactivation, nor do the enzymes alone cause inactivation. These results do not reveal whether or not the inactivation is enzymic, but do suggest that the process may not be due to a simple precipitation of the DNA by the antibiotic, since this would be expected to occur as readily, or even better, at $0^{\circ}$.

\section{DISCUSSION}

Adams (1959) suggested that antibiotics usually prevent phage formation only to the extent of their antibacterial properties. An earlier report of a differential inhibition of phage by streptomycin has been made by Edlinger (1949) for a staphylococcal phage. The brief data reported by him suggest that the mechanism of action of the antibiotic may be similar to that described above, but Edlinger did not carry the investigation this far. Bourke, Robbins \& Smith (1952) showed an inhibition by streptomycin of lysis induced in Escherichia colistrain B by T 2 bacteriophage, but the effect they studied seems to be different from that reported here since Brock (1962) has shown that streptomycin does not reduce the number of plaques formed by $\mathrm{T} 2$ on a streptomycin-resistant strain of $E$. coli. Jones (1945) and Cohen (1947) have shown that high concentrations of streptomycin slowly inactivate free phage, but this again is a different phenomenon from that reported here. Graham (1953) showed that streptomycin inhibits superinfection breakdown in T2-infected $E$. coli, but his data indicate that this was because of inhibition of a phage-specific DNAse. Graham \& Nelson (1954) showed that streptomycin affected a Streptococcus lactis bacteriophage only to the extent that it affected the host bacteria. They did show, however, a phage-specific effect of crystal violet, although in only two of 43 phages tested. Finally Reiter \& Oram (1962) have shown that suranim affects a $S$. lactis bacteriophage by inhibiting adsorption.

In the present work it has been shown that a wide variety of bacteriophages attacking various strains of Streptococcus faecalis, $S$. faecium, $S$. liquefaciens, and $S$. zymogenes are specifically inhibited by streptomycin. The fact that not all phages are inhibited indicates that the inhibition is a phage-specific, rather than a hostspecific phenomenon. Earlier work (Brock, 1962) has shown that in Escherichia coli only an RNA phage was affected by the antibiotic.

An analysis of the data in the present paper indicated that streptomycin has two effects. If added before phage adsorption, it seems to inhibit the injection 
mechanism, and the phage particle may remain attached to the cell and be carried along through a large number of divisions. This action of the antibiotic is readily and instantly reversible by dilution. If the antibiotic is added shortly after adsorption, or is again added to a culture from which it has just been removed by dilution, it now brings about a rapid inactivation of the phage genome. The rate of inactivation depends upon the temperature so it may be enzymatic, although added DNAse or chymotrypsin had no effect. The details of the inactivation process remain to be worked out.

If the streptomycin is again added 6 min. after injection begins, it has no effect on phage replication, and a burst occurs after the normal latent period of about $35 \mathrm{~min}$. If the antibiotic is added at any time between 1 and $4 \mathrm{~min}$. after injection begins, inactivation occurs. It thus seems reasonable to conclude that the time for complete injection is 5-6 min. Once injection has occurred, the phage genome is in a site inaccessible to the antibiotic. Recent work (Brock \& Wooley, 1963) using high-speed blending has confirmed that streptomycin inhibits injection.

Bradley \& Kay (1960) have studied the morphology of a variety of bacteriophages, using the phosphotungstic acid negative-staining technique. They have shown that the long-tailed phages fall into two groups. In one, the phages have contractile sheaths probably associated with the injection mechanism. In the other group, contractile sheaths are lacking, and another means of injection probably exists. Phage P9 has been studied in detail under the electron microscope and phages P1, P4, P10, P13 and P15 have been examined briefly. All are long-tailed phages with no evidence of contractile sheaths. Phage P3, which is streptomycinresistant, has a head size of about $60 \mathrm{~m} \mu$ and a tail size of about $200 \mathrm{~m} \mu$, and thus is not grossly different from the streptomycin-sensitive phages.

In addition to its usefulness in analysing the mode of injection of a phage nucleic acid, streptomycin can be used to advantage in classifying various bacteriophages. Once streptomycin-resistant host mutants are available, the determination of antibiotic sensitivity is a simple task. It would be very useful to know the streptomycin sensitivity of a wide variety of phages, especially for Gram-positive bacteria. At least one staphylococcal phage is streptomycin-sensitive (Edlinger, 1949).

If streptomycin sensitivity is associated with some aspect of the injection mechanism, this characteristic might be used as a genetic marker of high selective value. However, attempts to isolate streptomycin-resistant mutants of phage P9 have been unsuccessful. It has also been impossible to demonstrate recombination between P 3 (streptomycin-resistant) and P9 (streptomycin-sensitive) but since these two phages are obviously quite unrelated, this result is not surprising.

Finally, this work presents a model of how an antiviral compound might work. Since the host cells are completely resistant to the antibiotic, it is hard to imagine how an antiviral agent might inhibit by attacking some part of the machinery which is essential for both bacterial and viral reproduction. Thus it is significant that the site of attack of the antibiotic is on a phase of reproduction before the phage genome is integrated into the cell. Bacterial viruses have probably evolved special mechanisms for penetrating the rigid bacterial cell wall, and this probably explains the universal occurrence of tails in phage particles which have large heads. Only the very small phages, such as $\emptyset X 174, M S-2$ and f2 seem to lack tails, but these phages are so small that they can probably pass directly through the cell-wall mesh and 
attach themselves to the cell membrane. Thus in all large bacterial viruses, an injection mechanism for the DNA is essential. The question arises whether animal viruses also have injection mechanisms for penetrating cells, or whether these viruses enter through an activity of the animal cell itself, such as pinocytosis or phagocytosis. Apparently little is known about the mechanism of penetration of animal viruses (Hirst, 1959), and an investigation of this process in a variety of cases might provide important clues for chemotherapy. It should be pointed out that successful chemotherapy can occur even if only a small portion of the virus life cycle is affected, since virus replication is a progressive process in which the particles that leave one cell attack other cells. Thus streptomycin, although affecting only the first four minutes of the P9 life cycle, can completely inhibit the formation of plaques even when more than $10^{10}$ infectious units are put on a plate. This is indeed successful and impressive chemotherapy.

The advice and assistance of Mr H. Lentz with the electron microscopy is gratefully acknowledged and the work greatly benefited from discussions with Dr Nobuto Yamamoto.

The work was supported by grant no. DA-CML-18-064-61-G13 from the U.S. Army Chemical Corps Biological Laboratories, and grant no. Am-04630-02 from The U.S. Public Health Service. One of the authors (T.D.B.) is a U.S.P.H.S. Research Career Development awardee (grant no. AI-K3-18,403). J.M. was a National Science Foundation Undergraduate Research participant.

\section{REFERENCES}

Adams, M. H. (1959). Bacteriophages. New York: Interscience Publishers, Inc.

Barnes, E. M. (1956). Tetrazolium reduction as a means of differentiating Streptococcus faecalis from Streptococcus faecium. J. gen. Microbiol. 14, 57.

Bourke, A. R., Robbins, M. L. \& Smith, P. K. (1952). Studies on the chemical inhibition of 'T2r + bacteriophage. J. Immunol. 69, 75 .

Bradley, D. E. \& KAy, D. (1960). The fine structure of bacteriophages. J. gen. Microbiol. 23, 553.

Brock, T. D. (1962). The inhibition of an RNA bacteriophage by streptomycin, using host bacteria resistant to the antibiotic. Biochem. biophys. Res. Comm. 9, 184.

Brock, T. D. \& Wooley, S. (1963). Mode of action of streptomycin as an antiviral agent. Science (in the Press).

Burton, K. (1956). A study of the conditions and mechanisms of the diphenylamine reaction for the colorimetric estimation of deoxyribonucleic acid. Biochem. J. 62, 315.

Chargaff, E. \& Davidson, J. N. (1955). The Nucleic Acids, vol. I, p. 301. New York: Academic Press Inc.

Conen, S. S. (1947). Streptomycin and deoxyribonuclease in the study of variations in the properties of a bacterial virus. J. biol. Chem. 168, 511.

Dawson, I. M., Suillue, E. \& Norris, J. R. (1962). The morphology of Bacillus cereus bacteriophages. J. gen. Microbiol. 28, 517.

Eduinger, E. (1949). Antibiotiques et lyse bactériophagique. 1. Protection des colonies développées à la périphérie de la zone d'action de la streptomycine contre l'action du bactériophage (Staphylococcus albus Twort et Staphylococcus aureus S3K). Ann. Inst. Pasteur, 76, 396.

Graham, A. F. (1953). The fate of the infecting phage particle. Ann. Inst. Pasteur, 84, 90.

Graham, D. M. \& Nelson, F. E. (1954). Inhibition of lactic streptococcus bacteriophage by crystal violet and other agents. J. gen. Physiol. 37, 121. 
Hirst, G. K. (1959). Virus-host cell relation. In Viral and Rickettsial Infections of Man. Ed. by T. M. Rivers and F. L. Horsfall. Philadelphia: Lippincott.

Jones, D. (1945). The effect of antibiotic substances upon bacteriophage. J. Bact. 50, 341. Loeb, T. \& ZiNder, N. D. (1961). A bacteriophage containing RNA. Proc. nat. Acad. Sci., Wash. 47, 282.

Reiter, B. \& Oram, J. D. (1962). Inhibition of a streptococcal bacteriophage by suramin. Nature, Lond. 193, 651. 